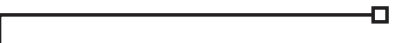

$\square$

Проведено аналіз циклів абсорбційних водоаміачних холодильних машини (АВХМ) в иирокому діапазоні робочих параметрів (температура гріючого середовища: $45 . .145^{\circ} \mathrm{C}$, температура навколишнього середовища: $10 \ldots 43^{\circ} \mathrm{C}$, температура об'єкта охолодження: мінус $25 . .5^{\circ}$ C). Показано позитивний вплив в розглянутих умовах роботи на енергетичну ефективність АВХМ низъких температур навколишнього повітряного середовища і високих температур, що гріє джерела тепла.

Розроблена перспективна система охолодження на базі АВХМ малої холодопродуктивності з використанням сонячної теплової енергї $i$ природного сезонного $i$ добового температурного потенціалу атмосферного повітря, в тому числі $і$ з технологією нічного радіаційного охолодження (НРО).

Ключовими елементами системи охолодження є: бак-холодоаккумулятор; система охолодження на базі АВХМ з комбінованими джерелами теплового навантаження; система відводу тепла в режимі конвекції $і$ радіаційного випромінювання в нічний час доби.

Показано, що АВХМ в комбінацї̈ з баком-холодоаккумулятором дозволяе забезпечити иирокий діапазон холодильної обробки за рахунок підбору робочої речовини з фазовим переходом (плавленням-затвердіння).

Рекомендовані робочі речовини з рівнем температур: мінус $25^{\circ} \mathrm{C}$ (для продукиї тваринного походження); $0^{\circ} \mathrm{C}$ (первинна холодильна обробка молока); $5{ }^{\circ}$ С (для плодоовочевої продукцї).

Гарантоване відведення тепла з бака-холодоаккумулятора системи охолодження в режимі пасивного «теплового діода» доцільно забезпечити за допомогою двофазних термосифонів.

При роботі з сонячними колекторами з водою, в якості теплоносія для генератора АВХМ, запропонована схема АВХМ з бустер-компресором перед конденсатором.

Показано, що найбільший ефект від технології НРО в системах відводу тепла може бути досягнутий в високогірних районах планети з мінімальною вологістю атмосферного повітря, наприклад, в Казахстані

Ключові слова: абсорбційна водоаміачна холодильна машина, холодопродуктивність, сонячні колектора, нічне радіаційне охолодження
UDC 621.575:620.91:662.997

DOI: $10.15587 / 1729-4061.2019 .164301$

\title{
DEVELOPMENT OF COOLING SYSTEMS ON THE BASIS OF ABSORPTION WATER-AMMONIA REFRIGERATING MACHINES OF LOW REFRIGERATION CAPACITY
}

\author{
A. Titlov \\ Doctor of Technical Sciences, \\ Professor, Head of Department \\ Department of Heat-and-Power Engineering \\ and Oil-and-Gas Transportation and Storing* \\ E-mail: titlov1959@gmail.com \\ E. O s a d c h u k \\ Senior Lecturer \\ Department of Mathematics* \\ A. Ts o y \\ $\mathrm{PhD}$, Associate Professor** \\ A. Alimkeshova \\ Postgraduate student** \\ R. Ja mas h e va \\ Postgraduate student** \\ E-mail: rita.adilovna@gmail.com \\ *Odessa National Academy of Food Technologies \\ Kanatna str., 112, Odessa, Ukraine, 65039 \\ **Department of Mechanization \\ and Automation of Production Processes \\ Almaty Technological University \\ Tole bi str., 100, Almaty, \\ Republic of Kazakhstan, 050012
}

d) primary refrigeration treatment in the field of the workpiece.

The implementation of these measures involves the crea-

In the modern world, the tasks of ensuring food security imply [1]:

a) formation of a network of procurement points;

b) creating conditions for expanding the number of objects of trade infrastructure;

c) improving the transport accessibility of remote areas to ensure the provision of basic types of food;

tion of a continuous cold chain, of which stationary primary refrigerators and transport refrigerators are an element.

Such refrigerators are in demand in farms and peasant farms. They can be used both in transport, and in stationary execution. In the first case - for delivery to the markets and procurement points of chilled and frozen agricultural 
products. In the second case - for the primary refrigerated processing and low-temperature storage of food products and raw materials in places of harvesting.

The use of compression models of refrigerators in all cases suggests the presence of electrical energy and certain temperature conditions during operation.

In stationary operating conditions, compression refrigerators use network electric energy, and when operating in transport conditions, energy that is produced using a diesel generator or energy stored in batteries.

In remote areas, in places of harvesting agricultural products, there are often problems with the supply of high-quality electrical energy, which leads to unstable operation of compression refrigerators.

For reliable operation of compression models of refrigerators, a certain outdoor temperature is also necessary, which excludes thickening of the oil in the compressor. The existing regulatory documents [2] allow the operation of compressors in the composition of refrigeration units only when the outside air temperature is above plus $10^{\circ} \mathrm{C}$.

When operating compression models in transport, it is assumed that additional fuel consumption for the operation of a diesel generator and the presence of a special compressor temperature control system provide certain temperature conditions for operation.

Interesting solutions to the problems of primary refrigeration processing and storage of agricultural products in places of harvesting and in transportation conditions can be found with the help of heat utilizing refrigerating machines. Such machines can operate on non-electric sources of thermal energy, including alternative renewable and waste heat sources $[3,4]$.

The most promising when working in areas with problem supply of electric energy and in transport are absorption water-ammonia refrigerating machine (AWARM) and pumpless-type units - absorption refrigeration machines (ARM) $[5,6]$.

Unlike bromide lithium analogs, they do not require mandatory liquid cooling of the heat dissipating elements (condenser, reflux condenser, absorber) and are much cheaper to manufacture because of the availability of structural materials (carbon steel) [7].

If to take into account the entire chain of production of electric energy at thermal power plants, then the energy efficiency of an energy economy becomes comparable with vapor compression analogues [8].

It is also important that the working body of AWARM and ARM is a natural working body - ammonia-water solution (AWS), which does not adversely affect the anthropogenic impact on the ecosystem of our planet [9].

Ammonia, on the other hand, as a refrigerant, allows to expand the scope of heat-utilizing refrigeration systems. Its working range is from minus $30^{\circ} \mathrm{C}$ (long-term low-temperature storage) to $0 \ldots 5^{\circ} \mathrm{C}$ (air conditioning systems and refrigerated processing of dairy and fruit-producing products) [10].

At the same time, the influence of atmospheric air temperatures on the performance and energy efficiency of machines and units of the absorption-ammonia type is also ambiguous and requires careful study.

The ambiguity of the impact is associated with the positive impact of low temperatures on the processes of heat removal of the refrigeration cycle to the environment with a simultaneous negative impact due to unplanned condensation of ammonia vapor on transport routes.
And if the features of the operation of ARM-based cooling systems in a wide range of outdoor air temperatures have already been sufficiently studied [11-14], then the system analysis of AWARM is absent in this part.

First of all, this applies to low refrigeration capacity AWARM (1-10 kW) with air-cooled heat dissipating elements (reflux condenser, condenser and absorber). Such cooling systems are in demand in various fields of application of artificial cold - from a continuous cold chain, including in farms and peasant farms, to systems for producing water from atmospheric air.

Only works $[15,16]$ on the study of AWARM with water and combined water-to-air cooling of heat dissipating elements are known.

In connection with the possible wide range of applications of AWARM low refrigeration capacity, an influence of the temperature level of thermal energy sources on their performance and energy efficiency should be studied.

Thus, the task of developing cooling systems based on low refrigeration capacity AWARM $(1-10 \mathrm{~kW})$ with aircooled heat dissipating elements (reflux condenser, condenser and absorber) becomes urgent.

\section{Literature review and problem statement}

In [11], a scheme of a cooling system based on a low refrigeration capacity AWARM is presented, which solves cooling problems in a wide range of operating temperatures (Fig. 1). The energy of solar radiation is considered as a source of heat and the possibility of additional compression of ammonia vapor before condensation is provided.

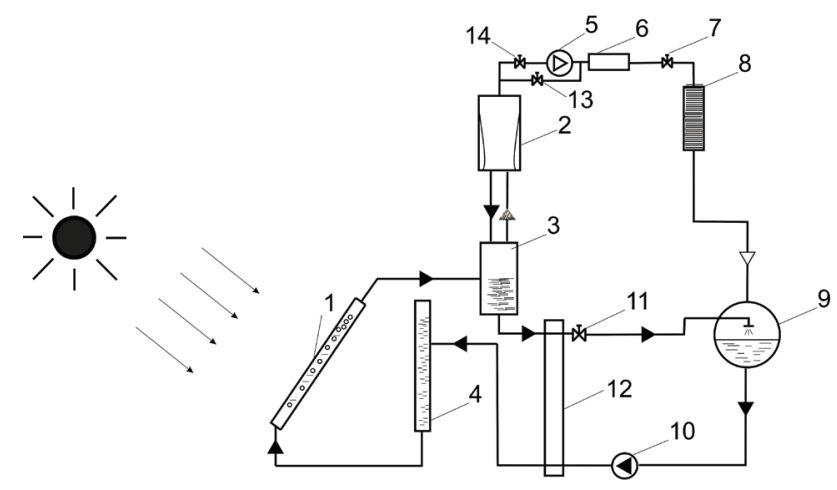

Fig. 1. Schematic diagram of the cooling system on the basis of low refrigeration capacity AWARM [11]:

1 - solar generator; 2 - reflux condenser; 3 - weak AWS receiver; 4 - strong AWS receiver; 5 - booster compressor; 6 - ammonia vapor condenser; 7 - liquid ammonia choke;

8 - evaporator; 9 - absorber; 10 - weak AWS circulation

pump; 11 - weak AWS choke; 12 - regenerative heat exchanger of strong and weak AWS; 13, 14-ammonia steam line stop valves

The scheme [11] can be adopted as a base for solving the problems of refrigeration processing in the conditions of poor-quality sources of electrical energy and, in this regard, let's consider it in more detail.

Solar radiation energy is supplied to solar generator 1 and mostly low-boiling ammonia is evaporated from strong AWS. Vapor bubbles push ammonia depleted in ammonia 
into the upper part of the solar generator. In the process of evaporation, the solution is depleted in ammonia and streams into the weak AWS receiver 3, and the vapor ammonia-water mixture (AWM) enters the reflux condenser 2. In the reflux condenser 2 , water vapor mainly condenses with the formation of reflux and heat removal of the phase transition to the environment. Reflux streams into the receiver 3 . From the reflux condenser, 2 ammonia vapor are fed via a booster compressor 5 to the condenser 6 , where it is compressed to the pressure $P_{k}$ and condensed with the removal of heat into the environment. From the condenser 6, liquid ammonia enters through the choke 7 enters the evaporator 8 . After the choke 7 , the pressure in the evaporator 8 and the absorber 9 decreases to $P_{o}$. In the evaporator 8 ammonia boils at a pressure $P_{o}$ and a temperature $t_{0}$ with the removal of heat $Q_{0}$ from the object of cooling.

The pressure $P_{o}$ in the evaporator 8 is maintained due to the continuous process of vapor absorption of ammonia by weak AWS in the absorber 9. In turn, the weak AWS enters the absorber 9 from the receiver 3 through the heat exchanger 12 and the choke valve 11 .

Formed after absorption of ammonia strong AWS is fed back to the receiver of a strong solution 4 by the circulation pump 10 and the cycle repeats.

The booster compressor [17] in the AWARM circuit [11] is designed to increase the condensation pressure $P_{c}$ in the case of low intensity of solar radiation (in the morning and evening hours or in cloudy weather). In this case, the valve 13 is closed, and the valve 14 is open. When the solar installation is sufficient for the vapor pressure of the ammonia installation, the situation with the valves is reversed.

The inclusion of a booster compressor in the scheme allows to significantly expand the performance in terms of the temperature level of the heating source. For example, it is necessary in circuits with solar collectors with water as a coolant [18], where the temperature does not exceed $100^{\circ} \mathrm{C}$.

At the same time, the question remains unclear about the influence of outdoor air temperatures on the air-cooled AWARM operation of its heat dissipating elements.

The well-known theoretical [13, 19, 20-25] and experimental studies [14, 21] show an unambiguous adverse effect of the elevated outdoor temperature on the energy efficiency of both AWARM and ARM.

Thus, the authors of [13] in the process of analyzing the operating modes of the ARM pumping thermosyphon-generator find some optimum temperatures and thermal loads, which allows to obtain the maximum energy efficiency of the refrigeration cycle. However, the results of the analysis [13] can't be used in the range of AWARM operation parameters.

A methodical approach to modeling AWARM and ARM cycles in a wide range of outdoor temperatures is known [20]; however, in [20] there are no results or recommendations on the peculiarities of working in such conditions.

The authors [25] propose to use a special composition of the ARM working body. A special absorber is introduced into AWS, which suppresses water vaporization during AWS boiling in the solar generator and increases the energy efficiency of the refrigeration cycle. As salts, lithium nitrate $\left(\mathrm{LiNO}_{3}\right)$ and sodium thiocyanate $(\mathrm{NaSCN})$ are considered.

At the same time, the authors [25] do not extend their recommendations to the range of AWARM operation parameters.

In [22], an analysis of ARM with a solar collector based on two-phase gravity-type thermosyphons is made (the heat source is located in the lower part, and the heat consumer is located at the top).
The ARM working body is a solution of lithium bromide and methanol, which can provide the necessary level of cooling temperatures to obtain water from atmospheric air, and the temperature of the heating source is $65-75^{\circ} \mathrm{C}$.

The work [24] focuses on the efficiency of the ARM generator node in terms of minimizing heat losses from the working surface. This review presents data on various ARM working bodies, which are not applicable in the AWARM.

The potential positive effects of low outdoor temperatures are currently not studied systematically.

Only ways to compensate for off-design condensation of ammonia vapor in the reflux zone due to installation or additional thermal insulation in passive [12] and controlled mode [11] are proposed.

Recently, when searching for ways to save energy on refrigeration equipment, the possibility of indirect or direct use of natural cold is also being addressed. Seasonal [12] and diurnal [26] fluctuations in air temperature are also considered.

The low temperature potential of atmospheric air is used both to reduce heat leakage into the refrigerating chambers [12] and to intensify heat exchange on the heat dissipating surfaces of the ARM elements [26]. This experience does not apply when designing small refrigeration AWARM.

In the development of low refrigeration capacity AWARM to work in a wide range of operating temperatures can be used the experience of creating a universal ARM with automatically varying pressure of the working fluid [27]. The authors of [27] propose to change the pressure of an inert gas (hydrogen) and thereby ensure optimal temperatures for the realization of the refrigeration cycle at various outdoor air temperatures.

However, the proposal of the authors of [27] can only be used as a methodological approach, since there is no inert gas in the AWARM. By analogy, when creating a new technology, it is possible to consider the possibility of regulating the AWS composition under different operating conditions of AWARM.

When searching for ways to maximize the positive impact on the energy efficiency of the AWARM cycles of natural low temperatures of atmospheric air, attention should be paid to the so-called effect of «nighttime radiation cooling» (NRC) into outer space.

It is shown [28] that any solid surface facing the night sky, under certain conditions, can emit more thermal energy than it receives back from the environment. The NRC effect allows to maintain the temperature of the solid below the temperature of atmospheric air.

The use of NRC is largely determined by the climatic features of a particular region. In certain climatic conditions, refrigeration systems using radiation will work more efficiently than others. The influence of climate on the operation of systems of this type is studied in [29-31].

It is established that atmospheric parameters such as wind speed, air humidity, atmospheric transparency for infrared radiation in the range from 8 to 13 micrometers affect the NRC effectiveness [31].

Studies of the operation of refrigeration systems using NRC were carried out in many regions of the planet with different climatic conditions. This includes the northern regions of Thailand with a humid hot climate [32] and Copenhagen, Milan, Athens [33]. We studied the cooling regimes of office space during the warm period of the year (from May 1 to September 30). The possibility of cooling the material with a phase transition for the accumulation of cold created by the NRC is investigated. 
In Australia [34], the cost of the cooling system was attempted to be reduced by combining the NRC system with solar panels (photovoltaic panels).

In all studies [32-34], in the daytime, cooling of the radiator (cooling device) below the outdoor temperature was not achieved, because the absorbed solar energy exceeded the radiated thermal radiation.

At the same time, radiation cooling was, in general, feasible only at night, since suitable materials with high infrared emissivity did not provide for cooling in the daytime [35, 36]. As a dye, in particular, it is proposed to use a material with a high content of $\mathrm{TiO}_{2}$ compounds, which increases the emissivity of the surface [37].

Studies on the use of radiation for refrigeration systems are also conducted for a sharply continental climate, using the example of Kazakhstan [29, 38].

The authors of [38] show that in regions with a sharply continental climate, night-time radiation cooling can be used to reduce the temperature of a liquid streaming periodically.

For example, the scheme [38] can be used for primary cooling of milk immediately after its collection. The authors of [38] show that the surface area of $4 \mathrm{~m}^{2}$ allows the unit to provide refrigeration capacity from $140 \mathrm{~W}$ to $650 \mathrm{~W}$ throughout the year, depending on the weather conditions of the city of Ust-Kamenogorsk.

Thus, the works of researchers [28-38] show the energy efficiency of the NRC technology for objects of passive heat dissipation into the surrounding atmospheric air.

The experience gained [28-38] allows the use of NRC technologies in the design of cooling systems based on low refrigeration capacity AWARMs.

The instability during the day and season of solar thermal energy and the natural cyclical nature of the day and night shift make think about the stabilization of the processes of heat and mass transfer in the AWARM elements.

One of the known approaches to solving the problem of thermal stabilization is the use of heat-cold-accumulating materials.

Heat is accumulated to smooth out irregularities in the supply of heat load to the solar generator, and cold - to stabilize the temperature of the cooling object. For the accumulation of heat and cold, substances with a first-order phase transition, melting, are recommended [39].

Taking into account the recommendations [39] for cold storage, the following can be used: water ice (melting point $0{ }^{\circ} \mathrm{C}$ ); deodecane (melting point minus $10^{\circ} \mathrm{C}$ ); $n$-alkanes (melting point from minus $29.7^{\circ} \mathrm{C}\left(\mathrm{C}_{10} \mathrm{H}_{22}\right)$ to $\left.5.9^{\circ} \mathrm{C}\left(\mathrm{C}_{14} \mathrm{H}_{30}\right)\right)$.

For the stock of thermal energy in the considered range of working temperatures of $\mathrm{ABCM}$ (from 80 to $120^{\circ} \mathrm{C}$ ), solid petroleum waxes $\left(\mathrm{C}_{n} \mathrm{H}_{2 n+2}\right)$ with a heat of fusion of $150-220 \mathrm{~kJ} / \mathrm{kg}$ can be used depending on the composition.

Analysis of the known technical solutions has shown the possibility of using a number of technologies and developments in the creation of new cooling systems based on low refrigeration capacity AWARMs (with air cooling of heat dissipating elements).

At the same time, there is currently no methodological approach summarizing the experience of well-known studies and taking into account the peculiarities of the multifactor effect of external temperature parameters on the AWARM operation.

There is also no analysis of the possibilities of using alternative renewable sources of thermal energy in the range of AWARM operating parameters.
All this suggests that it is expedient to conduct a study devoted to the study of the features of the low refrigeration capacity AWARM operation in a wide range of operating parameters.

\section{The aim and objectives of research}

The aim of research is development of the principles for constructing cooling schemes based on low refrigeration capacity AWARM using alternative renewable heat sources and natural seasonal and daily temperature potential of atmospheric air.

To achieve the aim, the following objectives are set:

- to conduct analytical studies of AWARM cycles and determine the influence of the temperature of atmospheric air and the temperature of the heating heat source on the energy efficiency;

- to develop promising schemes for autonomous cooling systems based on low refrigeration capacity AWARM with the use of renewable sources of thermal energy and natural cold.

\section{Analysis of the results of analytical studies of} absorption water-ammonia refrigerating machines

A distinctive feature of AWARM is the interdependence of temperatures in characteristic processes of the cycle temperature of the heating medium $t_{h}$, temperature of the cooling medium $t_{\tau}$, temperature of the cooling object $t_{o b}$. Of the three temperatures, only two can be arbitrarily set [40,41].

Any refrigeration unit must provide a given level of cooling $\left(t_{o b}\right)$, and the unit itself must operate in appropriate climatic conditions, that is, at a given temperature of the cooling medium $t_{\tau t}$. Therefore, the real variable parameter can only be the temperature of the heating source $t_{h}$.

For the analysis, the AWARM scheme of low refrigerating capacity is used [11] (Fig. 1).

The initial data for the analysis are:

a) the temperature of the cooling medium $t_{w}$;

b) temperature of the cooling object $t_{o b}$;

c) temperature differences on elements that do not explicitly take into account the conditions of heat exchange and the under-recovery of heat:

$\Delta t_{0}$ - temperature difference between the object of cooling and the temperature of boiling ammonia in the evaporator;

$\Delta t_{h}$ - temperature difference between the stream of weak AWS and the heating heat source in the generator;

$\Delta t_{W K}, \Delta t_{W A}, \Delta t_{W D}$ - temperature pressure in the condenser, absorber, reflux condenser with a cooling medium (atmospheric air);

$\Delta t_{T O}$ - temperature difference between the streams of weak and strong AWS at the cold end of the regenerative heat exchanger of solutions.

The variable parameter is the temperature of the heating heat source $t_{h}$.

The main criterion of energy efficiency served as the conversion ratio of the AWARM refrigeration cycle:

$$
C O P=\frac{q_{o}}{q_{G}},
$$

where $q_{o}$ - specific refrigerating capacity of the AWARM evaporator, $\mathrm{kJ} / \mathrm{kg} ; q_{G}-$ specific heat load supplied to the AWARM generator, $\mathrm{kJ} / \mathrm{kg}$. 
The algorithm for calculating the thermodynamic parameters of the AWARM cycle is based on the classical method [40, 41].

At the first stage of analytical studies, a search is made for the temperatures of the heating source $\left(t_{h}\right)$, which would satisfy the AWARM operating conditions at a certain temperature of the cooling medium $\left(t_{w}\right)$ and the temperature of the cooling object $\left(t_{o b}\right)$.

Such a sequence of analytical studies is related to the fact that not all modes of AWARM operation can be organized at an insufficiently high temperature of the heating source.

For example, the level of cooling temperatures in an evaporator requires an appropriate pressure $P_{o}$ in both the evaporator and the absorber. The equilibrium temperature of a strong AWS in the absorber $t_{w . A}^{\prime \prime}$ must be higher than the temperature of the cooling medium. This allows to provide a moving temperature head for the removal of heat of absorption into the envi-

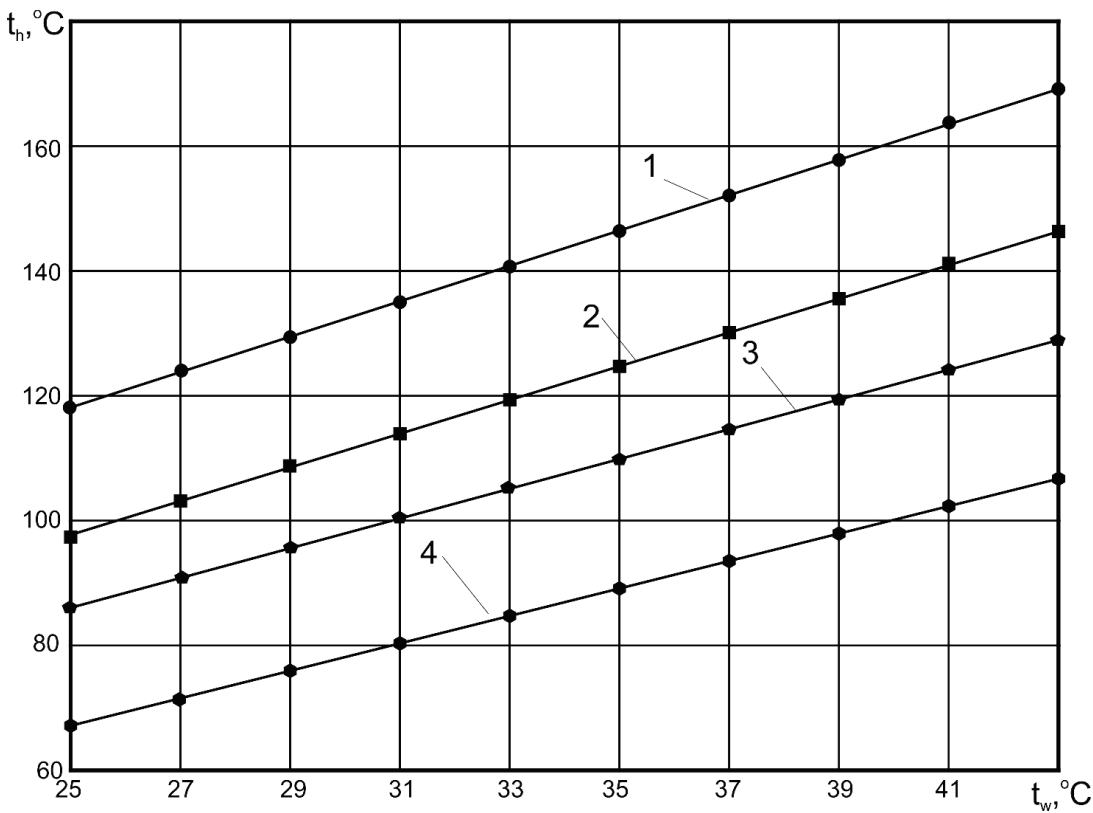

Fig. 2. The minimum required numerical values of the temperatures of the heating medium when the AWARM operates under the specified conditions: temperature of the cooling object $t_{o b}$ : $1-$ minus $30{ }^{\circ} \mathrm{C} ; 2-$ minus $15^{\circ} \mathrm{C} ; 3-$ minus $5{ }^{\circ} \mathrm{C} ; 4-5^{\circ} \mathrm{C}$ ronment.

The mass fraction of ammonia in strong AWS is determined by pressure $P_{o}$ and temperature $t_{w . A}^{\prime \prime}$, and to organize the absorption process, some degassing zone is necessary - the difference in mass fractions of ammonia in strong and weak AWS.

In turn, the mass fraction of ammonia in a weak AWS is determined by the values of the condensation-generation pressure $P_{o}$ and the temperature of the heating source $t_{h}$.

The booster compressor at the first stage of analytical studies is turned off and the pressure in the generator, the reflux condenser and the condenser is determined by the AWS composition and the conditions of heat exchange with the outside air.

The algorithm for searching the operating modes of AWARM consisted of the following.

The temperature of the cooling object $t_{o b}$ is set and a calculation is performed with a fixed value of the outdoor temperature $t_{w}$. For the given values $t_{o b}$ and $t_{w}$, let's calculate the multiplicity of the AWS circulation between the absorber and the generator with the variable $t_{h}$.

If the numerical values of the AWS circulation are positive, then it is concluded that the AWARM operating mode can be implemented, and otherwise, the operating mode does not exist.

The results of calculations of the minimum required numerical values of the temperatures of the heating medium when AWARM operates under specified conditions are presented in Fig. 2.

Analysis of the results in Fig. 2 shows that at elevated temperatures of the cooling medium $\left(36 \ldots 37^{\circ} \mathrm{C}\right)$ :

a) AWARM with a solar collector on water as a heat carrier can be used only in air conditioning systems and cooling chambers of fruits and vegetables;

b) AWARM with a temperature of cooling down to minus $30^{\circ} \mathrm{C}$. The temperature of the heating medium is $140 \ldots 150^{\circ} \mathrm{C}$.

At the second stage of analytical studies, the analysis of AWARM cycles is carried out in terms of the effect on the conversion coefficient of characteristic temperatures in the cycle.

The calculation results are shown in Fig. 3.

The choice when analyzing the range of outdoor temperatures of $10 \ldots 32{ }^{\circ} \mathrm{C}$ is associated with the current regulatory document determining the operating conditions of refrigeration equipment in Ukraine [2].

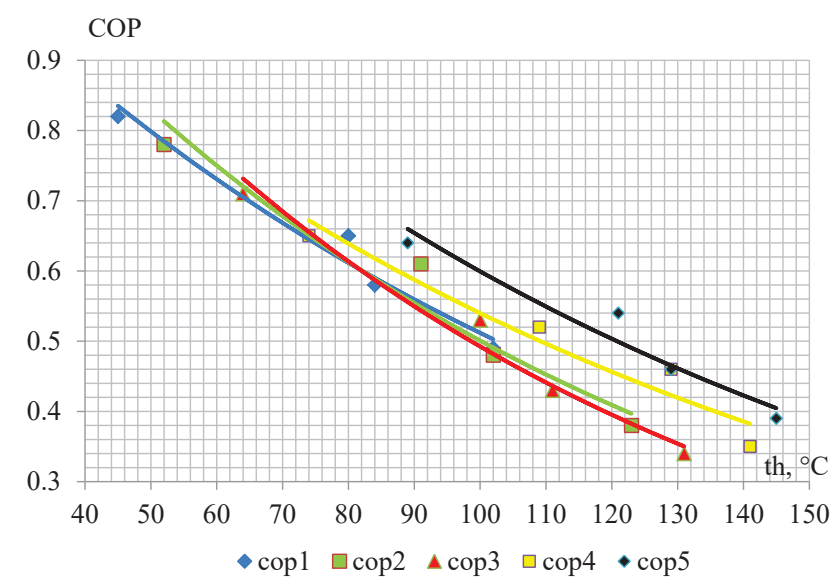

Fig. 3. The influence of characteristic operating temperatures on the AWARM cycle conversion coefficient:

$a$ - outdoor temperature: cop $1-10^{\circ} \mathrm{C}$; $\operatorname{cop} 2-15^{\circ} \mathrm{C}$; $\operatorname{cop} 3-20^{\circ} \mathrm{C}$; cop $4-25^{\circ} \mathrm{C}$; cop $5-32{ }^{\circ} \mathrm{C}$;

$b$ - the points on the graphs from top to bottom correspond to the temperature of the cooling object:

$1-5{ }^{\circ} \mathrm{C} ; 2-$ minus $5{ }^{\circ} \mathrm{C} ; 3-$ minus $15^{\circ} \mathrm{C} ; 4-$ minus $25^{\circ} \mathrm{C}$

The analysis presented in Fig. 3 results allows to draw the following conclusions.

a) Firstly, as the outdoor temperature decreases and the temperature of the cooling object rises, the energy efficiency of the AWARM cycle increases. So, for example, the maximum numerical values $C O P=0.82$ take place at an outdoor temperature of $10^{\circ} \mathrm{C}$ and a temperature of a cooling object 
of $5{ }^{\circ} \mathrm{C}$. At an outdoor temperature of $32^{\circ} \mathrm{C}$ and a temperature of the cooling object minus $25^{\circ} \mathrm{C}-C O P=0.39$.

In this case, the minimum required temperature of the heating medium is, respectively, $45^{\circ} \mathrm{C}$ and $145^{\circ} \mathrm{C}$.

b) Secondly, to obtain lower temperatures during the cooling treatment, it is required to increase the temperature level of the source of thermal load. In this case, the energy efficiency of the AWARM cycle will decrease. So, for example, when the outdoor temperature is $20^{\circ} \mathrm{C}$, the temperature of the cooling object is $5 \mathrm{C}$ and the heating source is $64{ }^{\circ} \mathrm{C}$, the numerical value is $C O P=0.73$. At the same outdoor temperature of $20^{\circ} \mathrm{C}$, the temperature of the cooling object is minus $25^{\circ} \mathrm{C}$, the minimum temperature of the heating source will be $131^{\circ} \mathrm{C}$, and the numerical value $C O P=0.35$.

At the third stage of analytical studies, an analysis of the capabilities of the booster-compressor on the «reflux-condenser» line on the energy characteristics of the AWARM cycle is carried out.

For the analysis, a complex is used that represents the ratio of the useful effect (obtained artificial cold) to the electrical power expended in the circulation pump and booster-compressor. The complex is previously called «modified refrigeration coefficient» $[19]$ or «modified conversion coefficient» of the AWARM cycle $\left(C O P_{m o d}\right)$.

When calculating $C O P_{\text {mod }}$, it is assumed that thermal energy in the AWARM generator comes from the sun and can be ignored. The results of energy efficiency calculations by $C O P_{\text {mod }}$ are shown in Fig. 4.

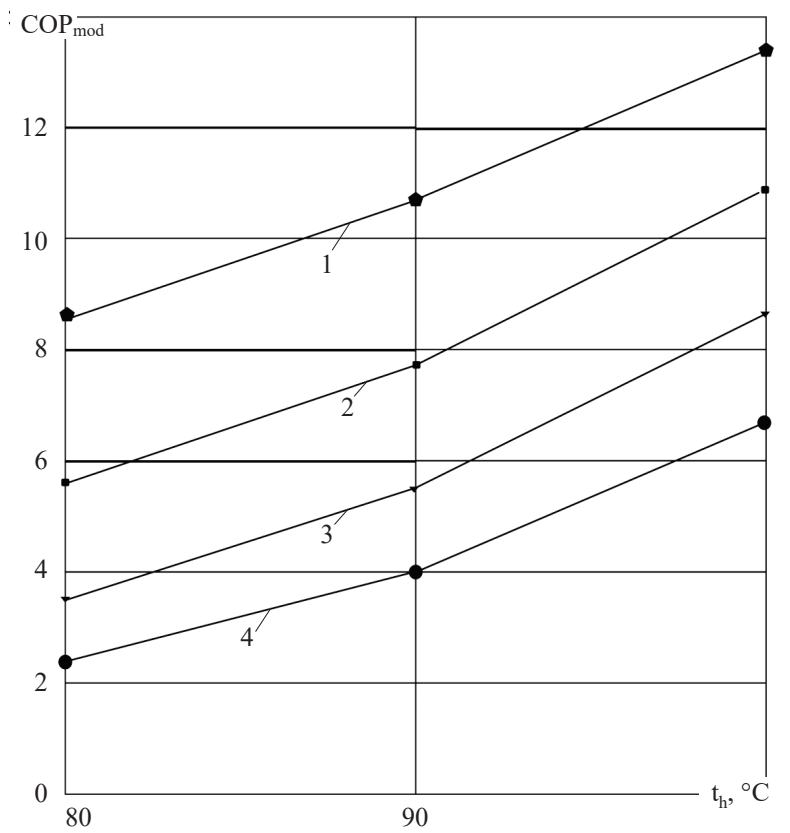

Fig. 4. Influence of the temperature of the heating medium and the outdoor temperature on the energy efficiency $\left(C O P_{\text {mod }}\right)$ of the AWARM cycle with a booster compressor at a fixed cooling object temperature of $5^{\circ} \mathrm{C}$ : outdoor temperature: $1-10^{\circ} \mathrm{C} ; 2-15^{\circ} \mathrm{C} ; 3-25^{\circ} \mathrm{C} ; 4-32{ }^{\circ} \mathrm{C}$

Analysis of the calculation results in Fig. 4 shows that:

a) the numerical values of the conversion coefficient $C O P_{\text {mod }}$ are incommensurable with the usual AWARM cycle without a booster compressor - they are higher by an order of magnitude or more; b) with an increase in the temperature of the heating source from $80^{\circ} \mathrm{C}$ to $100{ }^{\circ} \mathrm{C}$, the energy efficiency of the AWARM cycle increases almost 1.6...1.8 times;

c) with increasing outdoor temperatures, the energy efficiency of the AWARM cycle decreases.

For example, at a temperature of the heating medium of $90{ }^{\circ} \mathrm{C}$ and an outdoor air temperature of $10^{\circ} \mathrm{C}$, the numerical value of $C O P_{\text {mod }}=10.8$, and at an air temperature of $32{ }^{\circ} \mathrm{C}$ $C O P_{\bmod }=4.2$

The results of the analysis allow to substantiate the main provisions in the development of cooling systems based on low-capacity AWARM-based refrigerating capacity.

\section{Development of schemes for cooling systems based on low refrigerating capacity absorption water-ammonia refrigeration machines}

A schematic diagram of a cooling system based on low refrigerating capacity AWARM is shown in Fig. 5.

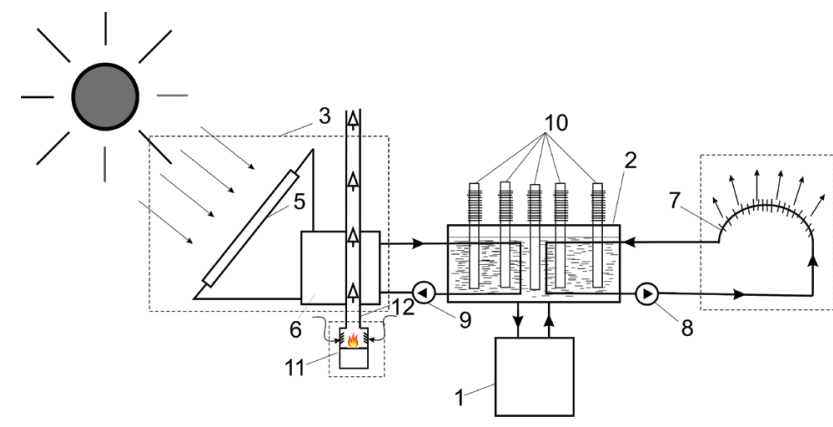

Fig. 5. Schematic diagram of the cooling system based on low refrigerating capacity AWARM:

1 - cooling object; 2 - cold storage tank;

3-AWARM-based cooling system; 4-system of thermal interaction with the environment; 5 - solar collector; 6 - AWARM; 7 - convection-radiation cooler of the cold-storage liquid; 8, 9 - circulation pumps of cold-storage fluid; 10 - two-phase thermosyphons; 11 - burner;

12 - exhaust pipe for removal of combustion products

The key elements of the cooling system are:

a) storage tank;

b) AWARM-based cooling system with combined sources of heat load (solar collector and burner);

c) heat removal system to atmospheric air, both in convection mode and radiation heat radiation into outer space at night.

Characteristic features of the proposed cooling system based on low refrigerating capacity AWARM are the following:

a) ability to work in a wide range of outdoor air temperatures in the modes of refrigeration storage and processing from minus $25^{\circ} \mathrm{C}$ to $5^{\circ} \mathrm{C}$;

b) minimal dependence on sources of electrical energy:

- operation of the AWARM booster compressor and the circulation pump 9 is assumed only under conditions of elevated outdoor temperatures in the daytime, when solar electric batteries or a burner can be operated;

- possibility of using a special battery of thermal energy (not shown in the figure) to smooth out fluctuations in the intensity of solar thermal radiation during daylight hours or variable cloudiness; 
c) possibility of using the natural temperature potential of atmospheric air and the NRC technology for «charging» the cold storage tank 2 :

- at night, with the help of a circulation pump 8 , heat is removed from the cold storage tank 2 both into the atmospheric air and into space;

- guaranteed heat removal in the «thermal diode» mode from the cold storage tank 2 using two-phase thermosyphons [43];

d) ability to work in different temperature conditions of cooling from minus $25^{\circ} \mathrm{C}$ to $0 \ldots 5^{\circ} \mathrm{C}$ by selecting the working fluid - cold accumulator.

\section{Discussion of the results of the development of thermodynamic parameters of AWARM cycles}

The results of the analysis of the thermodynamic parameters of the AWARM cycles in a wide range of operating parameters makes it possible to offer a new universal cooling system circuit with a refrigerating capacity from 1 to $10 \mathrm{~kW}$ with a minimum consumption of electrical energy.

The proposed scheme (Fig. 5) uses a renewable source of thermal energy (solar thermal radiation) and the natural temperature and radiation potential of the Earth's atmosphere.

During daylight hours, solar collectors with water as heat carrier (WSC) and parabolic solar collectors (PSC) can be used as a source of heat load for the AWARM generator.

WSCs solve the problem of heating to a temperature of $70 \ldots 80{ }^{\circ} \mathrm{C}$, and PSC - to a temperature of $200 \ldots 250{ }^{\circ} \mathrm{C}$ [44].

In the daytime, it is also possible to use solar panels to ensure the operation of circulation pumps, booster-compressor and automatic control systems.

The NRC technology makes it possible to use in cooling systems not only the natural low-temperature potential of atmospheric air, but also radiation into space.

In the cold season, the NRC technology allows to solve cooling problems without the participation of refrigerating machines.

In the transitional and warm period of the year, the NRC technology must be connected to artificial cooling systems.

AWARM round-the-clock operation can be achieved by operating the burner using, among other things, agricultural waste, as well as a paraffin-based heat accumulator.

The following can be attributed to the problem technical points of the proposed circuit solutions.
When starting even a low-power booster compressor, it is necessary to solve the problem of inrush currents. Modern electric batteries do not allow starting with currents exceeding 4-6 times the nominal values.

A solution to the problem can be a launch from a fixed power grid with a switch to solar panels.

Due to the low power of the booster compressor (up to $100 \mathrm{~W}$ ), a design with a direct current that has no problems with starting can be used in the scheme of the proposed AWARM.

The maximum energy effect from the use of NRC technology in refrigeration systems can be achieved in high-altitude regions of the planet with minimal atmospheric humidity, for example, in Kazakhstan and other countries of Central Asia.

The use of NRC in the composition of the cooling system with AWARM in other regions of the planet requires, first of all, experimental verification and assessment of economic feasibility

The results of the analysis are summarized in the form of a table (Table 1) of the recommended operating modes of cooling systems based on low refrigerating capacity AWARM under various operating conditions.

Analysis of recommended modes shows:

a) the burner device is mandatory when the AWARM operates in the low-temperature cooling modes from minus 25 to minus $5^{\circ} \mathrm{C}$;

b) at low outdoor air temperatures $\left(10^{\circ} \mathrm{C}\right)$, the booster compressor is not required;

c) a solar collector with water as a coolant can only be used in air conditioning systems and refrigerated storage of fruitful products.

Operating modes in Table 1are the first step (first approximation) to the creation of a design methodology and design of cooling systems of low refrigerating capacity using renewable sources of thermal energy.

First of all, to create the most autonomous and energyefficient cooling systems, it is proposed to use the natural temperature potential of atmospheric air at different times of the year and day. This is the technology of «night radiation cooling» and two-phase thermosyphons operating in the «thermal diode» mode and cold-storage materials with a wide range of operating temperatures.

These technologies and devices allow to provide «comfortable» operating conditions for AWARM, both in terms of heat removal from the refrigeration cycle to the environment, and in the production of artificial cold.

For this purpose, the features of AWARM operation in a wide range of atmospheric air temperatures were studied and presented in the form of graphical dependencies (Fig. 2-4).

Table 1

Recommended modes of operation of the cooling system on the basis of low refrigerating capacity AWARM in various operating conditions

\begin{tabular}{|c|c|c|c|c|c|c|c|c|c|c|c|c|c|c|c|c|}
\hline \multirow{3}{*}{$\begin{array}{l}\text { Temperature } \\
\text { condition of } \\
\text { the cooling } \\
\text { object, }{ }^{\circ} \mathrm{C}\end{array}$} & \multirow{3}{*}{ Type of cold storage } & \multicolumn{3}{|c|}{ WSC } & \multicolumn{3}{|c|}{ PSC } & \multicolumn{3}{|c|}{ B } & \multicolumn{3}{|c|}{ NRC } & \multicolumn{3}{|c|}{ B-C } \\
\hline & & \multicolumn{15}{|c|}{ Outdoor temperature, ${ }^{\circ} \mathrm{C}$} \\
\hline & & 10 & 20 & 32 & 10 & 20 & 32 & 10 & 20 & 32 & 10 & 20 & 32 & 10 & 20 & 32 \\
\hline Minus 25 & $\begin{array}{l}n \text {-alkanes (melting point from } \\
\text { minus } 29,7^{\circ} \mathrm{C}\left(\mathrm{C}_{10} \mathrm{H}_{22}\right) \text { to } 5.9^{\circ} \mathrm{C} \\
\left.\left(\mathrm{C}_{14} \mathrm{H}_{30}\right)\right)\end{array}$ & - & - & - & $+/-$ & $+/-$ & $+/-$ & + & + & + & - & - & - & - & + & + \\
\hline Minus 5...0 & $\begin{array}{l}\text { Deodecane (melting point mi- } \\
\text { nus } 10^{\circ} \mathrm{C} \text { ) }\end{array}$ & - & - & - & $+/-$ & + & + & + & + & + & $+/-$ & - & - & - & + & + \\
\hline 5 & Water ice & + & + & + & $+/-$ & + & + & $+/-$ & $+/-$ & $+/-$ & + & + & + & - & - & + \\
\hline
\end{tabular}

Note: WSC - a solar collector with water as a heat carrier; PSC - parabolic solar collector; B - burner; NRC - «night radiation» technology; B-C - booster compressor; «+» - it is necessary to use; «-»- impossibility of use; «+/-»- recommended for use 
In the second place, the technologies of using solar thermal radiation for the AWARM operation are proposed. They are also based on the results of analytical studies (Fig. 2-4) and allow to select sources of thermal energy of different temperature potential (WSC or PSC) depending on the operating conditions.

Natural insurance proposed cooling systems is a burner, which, regardless of the operating conditions, allows to provide the required temperature conditions.

The safety booster compressor on the ammonia vapor compression line in front of the AWARM condenser can also be attributed to safety technology. It allows to expand the range of opportunities for renewable sources of thermal energy even on traditional solar collectors with water as a coolant.

Regarding the field of application of developed AWARMbased cooling systems - despite the high rates of industrialization and electrification in the modern world, many countries have a significant number of territories where there are either no sources of power supply or their quality is unsatisfactory.

One of such examples is farms and peasant farms, which are located in places of harvesting and primary processing of products of animal and vegetable origin.

Particularly acute are the problems of quality assurance of the primary refrigerated processing of meat and dairy products in accordance with technological requirements. And, if in regions with a cold climate one can still use the long-known technology of using water ice, then in countries with a temperate and tropical climate, only artificial cooling should be used.

AWARMs with a refrigerating capacity of $1-10 \mathrm{~kW}$ can potentially close this niche of primary cooling systems for the volume of production of farms and peasant farms, for example, for primary cooling of milk.

\section{The system of primary milk cooling based on AWARM}

Let's consider, for example, the technology of using renewable and waste sources of thermal energy in the milk cooling system.

The cooling system (Fig. 6-8) contains a heat-insulated tank 1 with a lid 2 . At the bottom of the tank 1, a channel with a stop valve 3 is installed to periodically drain the cooled product. The collection and storage of chilled milk is carried out in a container 4 .

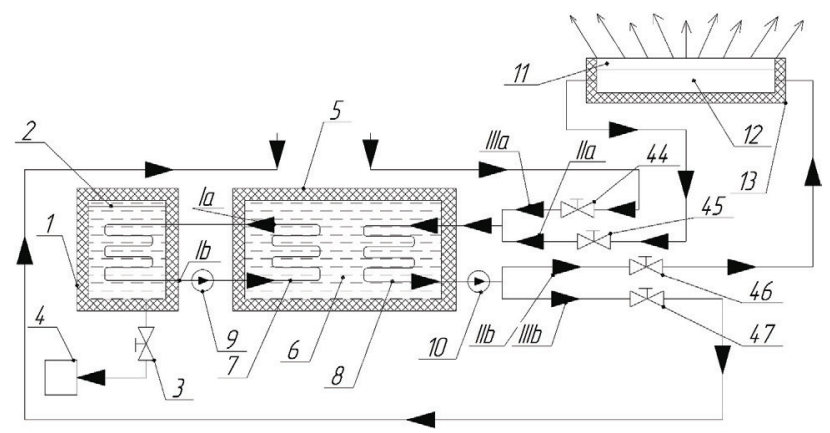

Fig. 6. Milk cooling system diagram:

1 - tank with milk, 2 - lid, 3 - stop valve, 4 - tank for milk, 5 - ice water storage tank, 6 - ice water,

7 - heat exchanger with water, 8 - heat exchanger with

brine, 9 - ice water circulation pump, 10 - brine pump,

11 - heat dissipation panel, 12 - duct system, 13 - thermal insulation coating, 44, 45, 46 and $47-$ valves

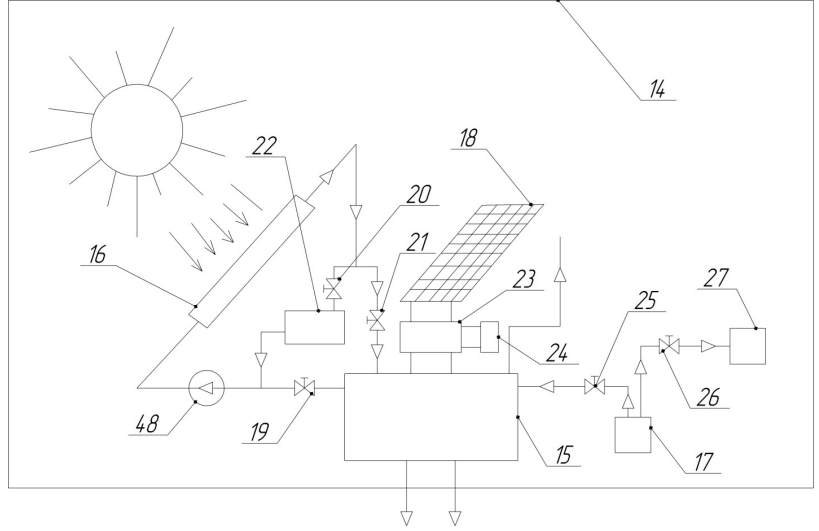

Fig. 7. AWARM-based artificial cold generation system: 14 - refrigeration system, 15 - AWARM, 16 - solar collector, 17 - flue gas generator, 18 - solar panels,

19,20 and 21 - stop valves, 22, 24 and 27 - heat consumers, $23-$ DC conversion system, 25 and 26 - stop and control valves, 48 - circulating pump

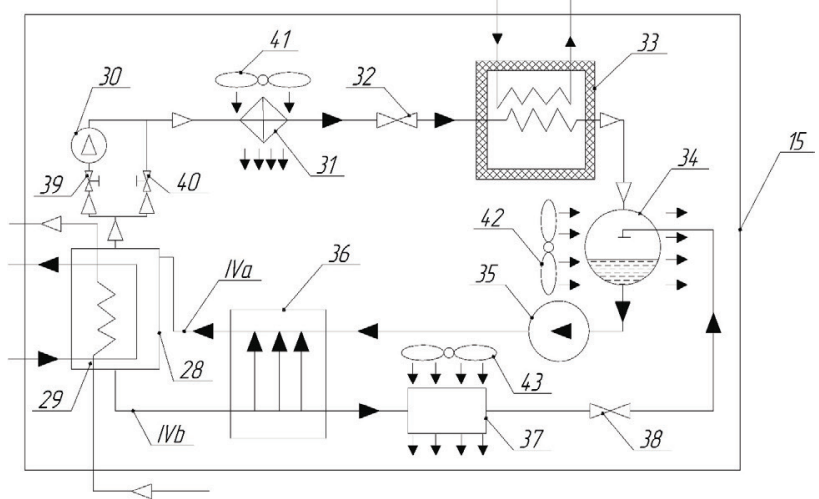

Fig. 8. AWARM scheme with booster compressor as part of the milk cooling system:

28 - generator, 29 - AWS, 30 - booster-compressor, 31 - air-cooled condenser, 32 - liquid ammonia throttle device, 33 - brine evaporator, 34 - air-cooled absorber, 35 - strong AWS circulation pump, 36 - regenerative solution heat exchanger, 37 - weak AWS air cooler, 38 - weak AWS throttle device, 39 and 40 - stop valves, 41,42 and 43 - AWARM air-scattering elements air fans

Inside the tank 1 through the heat exchanger 7 ice water circulates. The cold stream inlet is located in the upper part (Ia), and the outlet is in the lower part (Ib) of the tank 1. The cooling system also contains an ice water storage tank 5 with a thermal insulation coating. Tank 5 is filled with ice water 6 with a temperature close to $0{ }^{\circ} \mathrm{C}$. In the internal volume of the storage tank 5, heat exchangers 7 and 8 are installed.

Through the heat exchanger 7 , ice water (Ia and Ib streams) circulates through the pump 9, and brine circulates through the heat exchanger 8 - antifreeze fluid at a temperature close to $0^{\circ} \mathrm{C}$.

The entrance of the cooled brine stream to the storage tank 5 (streams IIa and IIIa) takes place in the upper part, and the heated brine stream (streams IIb and IIIb) leaves the lower part.

The cooling system contains a heat dissipating metal panel 11. Panel 11 is located either horizontally or with a certain angle to the horizon. The upper part of the panel is painted with light colors. Panel 11 is thermally connected 
with a system of channels 12 through which brine streams Ia and IIb circulate. The system of channels 12 and the lower part of the panel 11 is closed by a heat-insulating coating 13 .

The system includes an AWARM-based refrigeration system 14 (Fig. 7), designed to cool brine streams IIIa and IIIb. Brine streams IIa, IIb, IIIa and IIIb are controlled using shut-off valves 44, 45, 46 and 47 , respectively.

The refrigeration system 14 contains AWARM 15 with a system for supplying heat from the solar collector 16 and the flue gas generator 17 , as well as an autonomous power supply system based on solar batteries 18 (Fig. 8).

The solar collector system 16 contains a circulating pump 48 and a system of stop valves 19, 20, 21 that supply hot heat carrier to both AWARM 15 and other heat consumers 22 .

The autonomous power supply system contains a direct current conversion system 23 with the ability to supply the produced electrical energy to other consumers 24 .

The flue gas generator 17 contains a system of stop and control valves 25 and 26 , providing a stream of combustion products to the AWARM 15 and to other consumers 27.

AWARM 15 contains a generator 28 with a AWS 29, a booster-compressor 30, an air-cooled condenser 31, a liquid ammonia throttle device 32 , a brine evaporator 33, an air-cooled absorber 34, a strong AWS circulating pump 35 (stream IVa), a strong regenerative heat exchanger 36 and weak AWS, weak AWS air cooler stream 3 (stream IVb), throttle device weak VAR 38.

For cutting off the steam stream from the booster compressor 30, stop valves 39 and 40 are provided.

Air cooling of the condenser 31, the absorber 34 and the cooler 37 is carried out by fans, respectively, 41, 42 and 43 .

The operation of the AWARM-based milk cooling system is as follows.

Prior to the start of milk cooling, «charging» (cooling) of water in the storage tank 5 is carried out. To do this, use either the radiation cooling system - panel 11, or the refrigeration system 14. Accordingly, close valves 44 and 47 and open valves 45 and 46 , or vice versa.

When the temperature of the ice water reaches $1 \ldots 2^{\circ} \mathrm{C}$, the pump 9 is turned on and the streams Ia and Ib are pumped through the cooling cavity of the tank 1, and then the tank 1 is filled with warm milk. Due to heat exchange, the milk is cooled to a temperature of $4{ }^{\circ} \mathrm{C}$ and the cooled product is poured into a tank 4 for further use by means of a stop valve 3 .

Then the cycle of the cooling system is repeated.

Let's consider some modes of operation of the installation for cooling milk.

1. «Night» mode of cooling milk.

To cool the brine, a heat dissipation panel 11 is used, which provides brine cooling $5 \ldots 10^{\circ} \mathrm{C}$ below atmospheric air.

This cooling mode can be effectively used in winter and transition periods of the year (spring-autumn) without a refrigeration system.

The brine with the help of the pump 10 is pumped through the heat exchanger 8 with the valves 46 and 45 open and the valves 44 and 47 closed. The brine is cooled in the channels 12 due to the radiation cooling of the plate 11 .

In the «night» mode, both the natural cold of the Earth's atmosphere and radiation into space are used, and electrical energy is used only for the operation of the circulation pump 10.

2. «Day» mode of cooling milk.

A refrigeration system 14 is used with valves 44 and 47 open and valves 46 and 45 closed. The brine is pumped through pump 10 through evaporator 33 of AWAR 15 .
In the «day» cooling mode, it is possible to select two modes of operation of the refrigeration system 14.

In the first case, only a renewable source of thermal energy is used - solar thermal radiation.

The most widely used solar collector 16 with water as a heat carrier is used as a receiver of solar radiation. Their characteristic feature is the working temperature level not higher than $100{ }^{\circ} \mathrm{C}$

If there is no need for artificial cold, the heat flux from the solar collectors can be switched to other consumers of thermal energy 22 with the valve 20 open and valves 19 and 21 closed.

The operating temperature level in the generator of traditional AWARM is $120 \ldots 140^{\circ} \mathrm{C}$, which exceeds the available temperature potential of the heat-carrier water in the solar collector 16. In this connection, an AWARM circuit with a boost booster compressor 30 in front of the condenser 31 is used booster compressor 30 from the vapor stream stop valve 39 when changing the temperature parameters of the heat load to the generator 28 .

AWARM 15 operation with a solar collector 16 is as follows.

When hot water is supplied from the solar collectors to the generator 28, a strong AWS boils with the output of a predominantly low-boiling component - ammonia. When ammonia vapor is supplied to the booster-compressor 30, the valve 39 is open and the valve 40 is closed.

The ammonia vapor is compressed by the booster compressor 30 and fed to the condenser 31, where it is liquefied with the removal of the heat of vaporization into the environment. The heat removal of the phase transition from the condenser 31 is carried out using a fan 41.

Liquefied ammonia from the condenser 31 through the throttle device 32 enters the evaporator 33, where its pressure drops. Low-temperature boiling of liquid ammonia occurs with heat removal from the circulating brine stream. Formed in the evaporator 33 pairs enters the absorber 34, which, in turn, passes the weak AWS from the generator 28 .

Before entering the absorber 34, weak AWS is cooled in the regenerative countercurrent heat exchanger of solutions 36 and cooler 37 and as a result becomes ammoniated unsaturated. In the absorber 34, when a weak AWS contacts the ammonia vapor, an absorption process takes place - the absorption of ammonia by weak AWS. As a result, a weak AWS is saturated and becomes «strong» (saturated in ammonia). In the absorption process, heat is generated, which is discharged by the fan 42 to the environment. Strong AWS from the absorber by pump 35 through the regenerative heat exchanger 36 is fed back to the generator 28 and the cycle then repeats.

The operation of the booster compressor 30 and the pump 35 is carried out by the operation of the solar battery 18 and the system for converting and storing electrical energy 23. The system 23 also allows redistributing, if necessary, electrical energy for other consumers 24.

In the second mode of operation of the refrigeration system 14, the supply of heat load to the generator 28 of AWARM 15 is carried out by flue exhaust products with a temperature of $350 \ldots 450{ }^{\circ} \mathrm{C}$ from the gas generator 17 .

In this case, a wide range of organic fuels can be used: natural gas, propane-butane, gasoline, kerosene, coal, firewood, peat, etc.

The temperature potential of the stream of products of combustion is sufficient for the AWARM 15 to operate without the participation of a compressing booster compressor 30 . In this case, the valve 39 is closed and the valve 40 is open. 
The work of AWARM 15 is further carried out as described above.

The second method of operation of the refrigeration system 14 is implemented in cloudy weather and in the dark or gloomy time of the day.

Thus, the AWARM-based cooling system allows with the minimum cost of the network electric power and water to carry out the primary cooling of milk in the conditions of peasant and private farms.

\section{Conclusions}

1. The analysis of AWARM cycles in a wide range of operating parameters (temperature of the heating medium: from 45 to $145^{\circ} \mathrm{C}$, outdoor temperature: $10 \ldots 43^{\circ} \mathrm{C}$, temperature of the cooling object: minus $25 \ldots 5^{\circ} \mathrm{C}$ ). It is shown that under the considered operating conditions, the positive effect on the AWARM energy efficiency of the is low outdoor air temperatures and high temperatures of the heating heat source.

2. A promising cooling system based on low refrigerating capacity AWARM is developed using solar thermal energy and the technology of using natural seasonal and daily temperature potential of atmospheric air, including using NRC.

The operating modes of AWARM allow to provide a wide range of refrigeration processing by selecting a cold-accumulator with a phase transition (melting-solidification) with an appropriate temperature level:

a) from minus $25^{\circ} \mathrm{C}$ (low-temperature storage of products of animal origin);

b) $0{ }^{\circ} \mathrm{C}$ (primary refrigerated processing of milk);

c) $5{ }^{\circ} \mathrm{C}$ (storage of fruit and vegetable products).

It is advisable to ensure the guaranteed heat removal from the cold storage tank of the cooling system in the passive «thermal diode» mode with the help of two-phase thermosyphons.

When working with solar collectors with water, as a coolant for the AWARM generator, the AWARM scheme with a booster compressor in front of the condenser is proposed.

The results of the analysis are summarized in the form of recommended operating modes of cooling systems based on low-cooling AWARM base in various temperature conditions of operation, taking into account the possibilities of sources of renewable thermal energy and passive heat removal systems.

\section{References}

1. Pro prodovolchu bezpeku Ukrainy: Zakon Ukrainy No. 8370-1 za stanom na 28.04.2011 r. // Verkhovna Rada Ukrainy. Kyiv: Parlam. Vyd-vo, 2011.

2. DSTU 3023-95 (HOST 30204-95, ISO 5155-83, ISO 7371-85, ISO 8187-91). Prylady kholodylni pobutovi. Ekspluatatsiyni kharakterystyky ta metody vyprobuvan. Kyiv, 1996. 22 p.

3. Perel'shteyn B. H. Novye energeticheskie sistemy. Kazan': Izd-vo Kazan. gos. tekhn. un-ta, 2008. 244 p.

4. Tataurov O. Holod - Solnce. Dlya izobretateley i inzhenerov holodil'naya tekhnika na al'ternativnyh istochnikah energii - bogateyshee pole dlya tvorchestva // Holodil'niy biznes. 2009. Issue 7. P. 18-20.

5. Ishchenko I. M. Rozrobka metodyky rozrakhunku transportnykh absorbtsiynykh kholodylnykh pryboriv dlia bezperervnoho kholodylnoho lantsiuha // Naukovi pratsi Odeskoi natsionalnoi akademii kharchovykh tekhnolohiy. 2009. Vol. 1, Issue 35. P. 174-178.

6. Analysis of prospects for use on vessels pumpless absorption-type refrigerating units / Titlov A. S., Gozhelov D. P., Shlapak G. V., Redunov G. M. // Refrigeration Engineering and Technology. 2015. Vol. 51, Issue 3. P. 62-65. doi: https://doi.org/10.15673/ 0453-8307.3/2015.42638

7. Dincer I., Ratlamwala T. A. H. Developments in Absorption Refrigeration Systems // Integrated Absorption Refrigeration Systems. 2016. P. 241-257. doi: https://doi.org/10.1007/978-3-319-33658-9_8

8. Yildiz A. Thermoeconomic analysis of diffusion absorption refrigeration systems // Applied Thermal Engineering. 2016. Vol. 99. P. 23-31. doi: https://doi.org/10.1016/j.applthermaleng.2016.01.041

9. Doroshenko A. V., Glauberman M. A. Al'ternativnaya energetika. Solnechnye sistemy teplohladosnabzheniya. Odessa: Odessk. nac. un-t im. I. I. Mechnikova, 2012. 447 p.

10. Korba E. N., Hmel'nyuk M. G. Prirodnye hladagenty i ih smesi kak novye «starye» rabochie tela holodil'nyh mashin // Refrigeration Engineering and Technology. 2008. Issue 4. P. 16-20.

11. Improving the energy efficiency of solar systems for obtaining water from atmospheric air / Kholodkov A., Osadchuk E., Titlov A., Boshkova I., Zhihareva N. // Eastern-European Journal of Enterprise Technologies. 2018. Vol. 3, Issue 8 (93). P. 41-51. doi: https:// doi.org/10.15587/1729-4061.2018.133643

12. Selivanov A. P. Absorbcionnye holodil'nye apparaty sezonnogo tipa. Sovremennoe sostoyanie i tendencii razvitiya // Zbirnyk naukovykh prats Natsionalnoho universytetu korablebuduvannia. 2013. Issue 5-6. P. 82-88. URL: http://nbuv.gov.ua/UJRN/ znpnuk_2013_5-6_17

13. Titlova O. A., Titlov A. S. Analiz vliyaniya teplovoy moshchnosti, podvodimoy v generatore absorbcionnogo holodil'nogo agregata, na rezhimy raboty i energeticheskuyu effektivnost' absorbcionnogo holodil'nogo pribora // Naukovi pratsi Odeskoi natsionalnoi akademiyi kharchovykh tekhnolohiy. 2011. Vol. 1, Issue 39. P. 148-154.

14. Ishchenko I. N. Modelirovanie ciklov nasosnyh i beznasosnyh absorbcionnyh holodil'nyh agregatov // Naukovi pratsi Odeskoi natsionalnoi akademiyi kharchovykh tekhnolohiy. 2010. Vol. 2, Issue 38. P. 393-405.

15. Srinivas Garimella Interim Report: Fundamental understanding of heat and mass transfer in the ammonia/water absorber. Air-conditioning and refrigeration technology institute Under ARTI 21CR Program Contract Number. 2006. URL: https://ru.scribd.com/ document/185766866/Tranferencia-de-Mas 
16. Kim D. S., Infante Ferreira C. A. Final report K-SOLAR: Air-cooled solar absorption air conditioning. Delft University of Technology, 2005.

17. Sposib oderzhannia vody z atmosfernoho povitria: Pat. No. 104854 UA / Kuzakon V. M., Vasyliv O. B., Titlov O. S., Osadchuk Ye. O. No. u201507386; declareted: 23.07.2015; published: 25.02.2016, Bul. No. 4.

18. Morosuk L. I. Development and improvement of the heat using refrigerating machines // Refrigeration Engineering and Technology. 2014. Vol. 50, Issue 5. P. 23-29. doi: https://doi.org/10.15673/0453-8307.5/2014.28695

19. Osadchuk E. A., Titlov A. S., Mazurenko S. Yu. Determination of power efficient operating conditions of absorption water-ammonia refrigerating machine in the systems for obtaining water from atmospheric air // Refrigeration Engineering and Technology. 2014. Vol. 50, Issue 4. P. 54-57. doi: https://doi.org/10.15673/0453-8307.4/2014.28054

20. Titlov A. S. Nauchno-tekhnicheskie osnovy energosberezheniya pri proektirovanii holodil'nyh apparatov s absorbcionno-diffuzionnymi holodil'nymi mashinami // Naukovi pratsi Odeskoi natsionalnoi akademiyi kharchovykh tekhnolohiy. 2006. Vol. 1, Issue 29. P. $194-200$.

21. Mirmov I. N. The use of solar energy and secondary sources of heat to produce cold // Holodil'naya tekhnika. 2011. Issue 9. P. 44-48.

22. Yildiz A., Ersöz M. A., Gözmen B. Effect of insulation on the energy and exergy performances in Diffusion Absorption Refrigeration (DAR) systems // International Journal of Refrigeration. 2014. Vol. 44. P. 161-167. doi: https://doi.org/10.1016/ j.ijrefrig.2014.04.021

23. El-Shaarawi M. A. I., Said S. A. M., Siddiqui M. U. Comparative analysis between constant pressure and constant temperature absorption processes for an intermittent solar refrigerator // International Journal of Refrigeration. 2014. Vol. 41. P. $103-112$. doi: https://doi.org/10.1016/j.jjrefrig.2013.12.019

24. Acuña A., Velázquez N., Cerezo J. Energy analysis of a diffusion absorption cooling system using lithium nitrate, sodium thiocyanate and water as absorbent substances and ammonia as the refrigerant // Applied Thermal Engineering. 2013. Vol. 51, Issue 1-2. P. 1273-1281. doi: https://doi.org/10.1016/j.applthermaleng.2012.10.046

25. Ishchenko I. M., Titlov O. S. Improvement of regime parameters of water-absorbing ammonia refrigeration units operating in a wide range of ambient temperatures // Refrigeration Engineering and Technology. 2018. Vol. 54, Issue 3. P. 10-20. doi: https://doi.org/10.15673/ret.v54i3.1096

26. Titlov O. S., Ischenko I. M. Method of controlling the absorption refrigerating device: Pat. No. 111387 UA. No. a201406025; declareted: 02.06.2014; published: 25.04.2016, Bul. No. 8.

27. Kimball B. A. Cooling performance and efficiency of night sky radiators // Solar Energy. 1985. Vol. 34, Issue 1. P. 19-33. doi: https://doi.org/10.1016/0038-092x(85)90089-1

28. Climate influence on the operation of refrigeration system using the effective radiation into space / Tsoy A. P., Granovsky A. S., Tsoy D. A., Baranenko A. V. // Holodil'naya tekhnika. 2014. Issue 12. P. 36-41.

29. Yong C., Yiping W., Li Z. Performance analysis on a building-integrated solar heating and cooling panel // Renewable Energy. 2015. Vol. 74. P. 627-632. doi: https://doi.org/10.1016/j.renene.2014.08.076

30. Zhou Z., Sun X., Bermel P. Radiative cooling for thermophotovoltaic systems // Infrared Remote Sensing and Instrumentation XXIV. 2016. doi: https://doi.org/10.1117/12.2236174

31. Prommajak T., Phonruksa J., Pramuang S. Passive cooling of air at night by the nocturnal radiation in Loei, Thailand // Int. J. Renew. Energy. 2008. Vol. 3, Issue 1. P. 33-40.

32. Simulation Study of Discharging PCM Ceiling Panels through Night - time Radiative Cooling / Bourdakis E., Kazanci O. B., Grossule F., Olesen B. W. // ASHRAE Annual Conference. 2016.

33. A Feasibility Study of Night Radiative Cooling of BIPVT in Climatic Conditions of Major Australian Cities / Imroz Sohel M., Ma Z., Cooper P., Adams J., Niccol L., Gschwander S. // Asia - Pacific solar research conference. 2014.

34. Reproducibility of solidification and melting processes in a latent heat thermal storage tank / Bosholm F., López-Navarro A., Gamarra M., Corberán J. M., Payá J. // International Journal of Refrigeration. 2016. Vol. 62. P. 85-96. doi: https://doi.org/ 10.1016/j.ijrefrig.2015.10.016

35. The Use of Low-temperature Potential of the Environment in Energy-efficient Refrigeration Supply Technologies of the Enterprises of GC «Titan» / Sutyaginsky M. A., Maksimenko V. A., Potapov Y. A., Suvorov A. P., Dubok V. N. // Procedia Engineering. 2016. Vol. 152. P. 361-365. doi: https://doi.org/10.1016/j.proeng.2016.07.715

36. Berdahl P., Martin M., Sakkal F. Thermal performance of radiative cooling panels // International Journal of Heat and Mass Transfer. 1983. Vol. 26, Issue 6. P. 871-880. doi: https://doi.org/10.1016/s0017-9310(83)80111-2

37. Alekseev V. A. Osnovy proektirovaniya teplovyh akkumulyatorov kosmicheskih apparatov: monografiya. Kursk: Naukom, 2016. 248 p.

38. Galimova L. V. Absorbcionniy holodil'nye mashiny i teplovye nasosy. Astrahan': Izd-vo AGTU, 1997. 166 p.

39. Morozyuk T. V. Teoriya holodil'nyh mashin i teplovyh nasosov. Odessa: Studiya «Negociant», 2006. 712 p.

40. Sathyabhama A., Ashok B. Thermodynamic simulation of ammonia-water absorption refrigeration system // Thermal Science. 2008. Vol. 12, Issue 2. P. 45-53. doi: https://doi.org/10.2298/tsci0803045s

41. Vasil'ev L. L., Grakovich L. P., Hrustalev D. K. Teplovye truby v sistemah s vozobnovlyaemymi istochnikami energii. Minsk: Nauka i tekhnika, 1988. 159 p.

42. Solnechnaya teploenergetika // Elektroenergetika i ohrana okruzhayushchey sredy. Funkcionirovanie energetiki v sovremennom mire. URL: http://energetika.in.ua/ru/books/book-5/part-1/section-2/2-1/2-1-1 